\title{
EVALUATION OF TOURISM POTENTIAL IN DOGANKENT DISTRICT IN GIRESUN
}

\author{
Işık Sezen ${ }^{1}$ \\ Emine Patan'
}

\begin{abstract}
Tourism is defined to be the combination of events and relationships resulting from the travels and accommodation for temporary human activities lasting from at least two days to two years with the aims of performing activities like work, recreation, entertainment, experiencing different cultures and living styles and sport. There is absolutely a significant relationship between tourism and natural-cultural source values. Tourism can gain a shape in an area depending largely on natural and cultural source values there.

Turkey has multi-form and colored landscape diversity changing from city to city and region to region due to its natural characteristics like vegetation cover, climate, topography and soil structure and its cultural richness caused by the factors such as traditions and customs, folkloric and settlement features.

Color and form offered by the landscape in Blacksea region change into different colors and forms in East Anatolia and Aegean regions. Such diversity in landscape can offer possibility for also tourism.

In the present study, the district of Doğankent in the province of Giresun located in Blacksea region is evaluated. In the scope of the study, surveys were conducted in study area between 2011 and 2014 and natural and cultural values tried to be evaluated. It was determined according to the field surveys on natural and cultural reserves of Doğankent that the area may offer important opportunities for culture, gastronomy, flora, winter, nature and ${ }^{3}$ plateau tourism and should be evaluated for these tourism types.
\end{abstract}

Key words: Tourism, Doğankent, Giresun, East Blacksea Region, Turkey

\section{INTRODUCTION}

Derived from Latin word tornus, tourism expresses any type of travels, going around and moving from one location to another. Since travel and sightseeing require some expenses, tourismis an area creating possibilities of employment and bringing foreign currency for countries. Therefore, growth performed in any size in tourism sectordirectly affects national economies. In this respect, a need to diversify touristic activities has been on the agenda in order to increase the attractiveness and sustainability of tourism and its share in inter/national market (Kasalak, 2015). Tourism was defined by United Nations Environment Program (UNEP) in 1963 to be all the events and relationships resulting from the travels and temporary and not income generating accommodationsfor at least 24 hours (Tolungüç 1999).Formation of different cultures at different locations can create points in the world combining culture and geography and developing tourism. The simplest and basic definition of tourism is the travels and accommodations performed for the formation of different cultures, knowing these cultures, recreation and entertainment, sightseeing and seeing and learning different cultures and locations (Emekli, 2006).

\footnotetext{
${ }^{1}$ Assistant Professor, Department of Landscape Architecture, Faculty of Architecture and Design, University of Atatürk, Erzurum, Turkey.

${ }^{2}$ Research Assistant, Department of Landscape Architecture, Faculty of Architecture, İstanbul Technical University, İstanbul, Turkey.
} 
For Turkey, active international (incoming) tourism has been improving since especially 1980 s. With the economic program put into effect in 1985, tourism was included in the financially supported and promoted sectors and through the increased amount of investments in the field the sector turned out to be one of the sources contributing greatly to national economy (Çil Yavuz, 2006).

Depending on globalisation as in the other sectors in the world tourism also faced some gradual changes. Some new trends in the world based on demands are history, health, nature, culture and rural tourism. Countries or regions supplying such touristic potentials can achieve socioeconomic development in especially rural through the policies they made depending on touristic demand. Turkey can be counted among such countries since it can offer several alternatives due to its geographical location for history, health, culture and rural tourism (Çeken et al., 2007).

It is known that increasing trend of sought for alternative tourism activities from 1990s all over the world and the challenges for the diversification of tourism types confirmed that Turkey shelters potentials for nearly all tourism types to develop based on natural, historical and cultural attractiveness (Emekli, 2005). Turkey is rich in the existence of historical, cultural and natural beauties. The number of countries is not much where four seasons can be seen in the world. When all the factors are combined, a unique and excellent diversity is created in the country. In such richness and diversity, rural areas are the combination area of cultural and natural beauties (Gökalp and Yazgan, 2013). In the present study, the district of Doğankent in official border of Giresun province in East Blacksea Region of Turkey is evaluated and it was determined according to filed surveys carried out between 2011 and 2014 that natural and cultural resource values the district owns can offer possibility for especially plateau tourism, history and culture, flora, gastronomy, winter, sports and water based tourism activities and some suggestions were proposed for the sustainability of tourism activities in the area.

\section{MATERIAL AND METHOD}

Main material of the study dealing with the determination of tourism and recreational potentials of Doğankent (Giresun) district and its close proximity according to landscape planning principles is the district itself (Figure 1).

Total surface area of the district Doğankent, located in official border of Giresun province $\left(40^{\circ} 46^{\prime} \mathrm{N} 38^{\circ} 55^{\prime} \mathrm{E}\right)$, is nearly $123 \mathrm{~km}^{2}$ and its elevation is $190 \mathrm{~m}$. In the scope of the present study, first, natural and cultural landscape inventory of the study area and a database were prepared. After that, distribution of existing tourism destinations, touristic possibilities, infrastructure and related problems were evaluated to determine present tourism potentials of the study area. Method of the study includes the determination of the aim, choosing study area, literature review, data collection, inventorying natural and cultural source values in the area, determination of existent tourism potentials and after all the evaluations, the determination of proposed tourism types. 


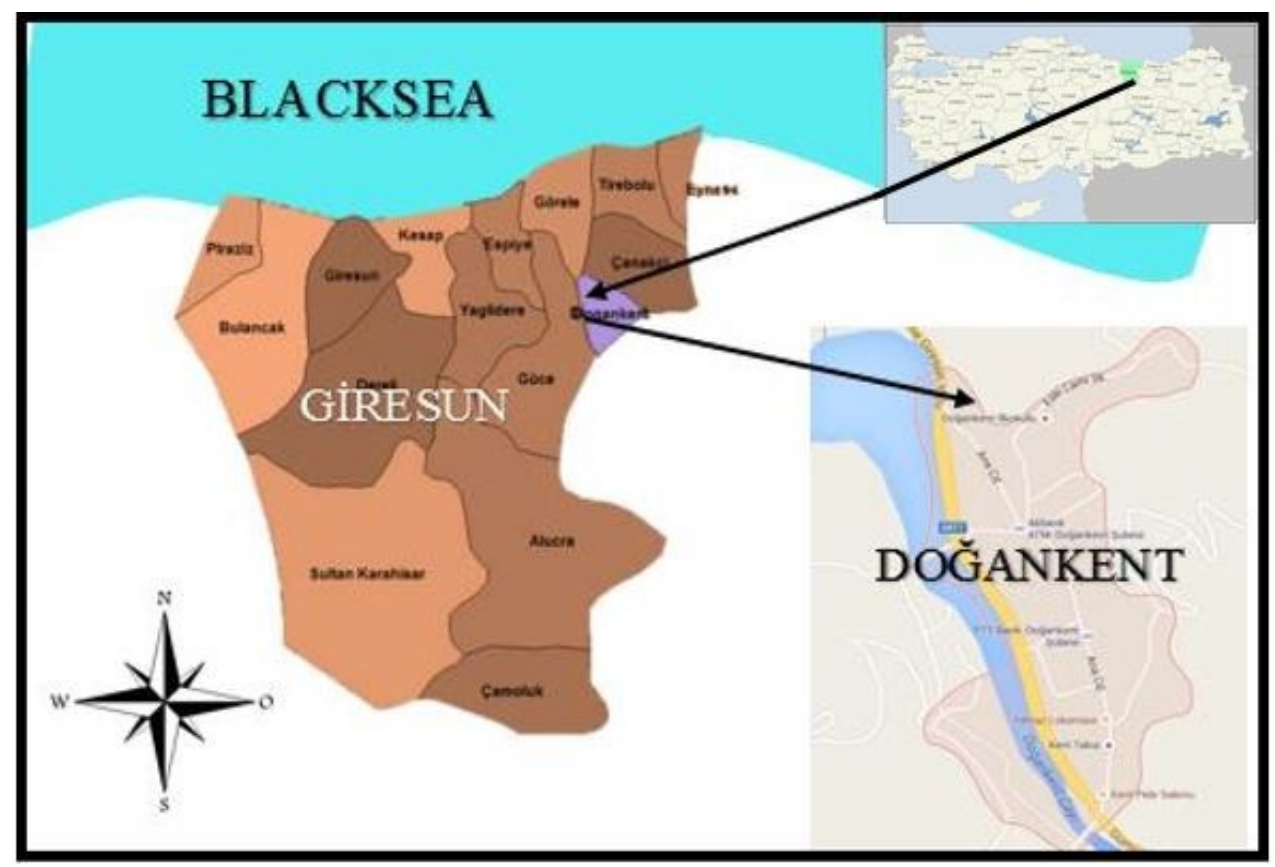

Fig. 1. Study material

\section{FINDINGS}

Thissection will mention about the source values and suitable areas existing in the study area for history and culture, gastronomy, winter, nature, plateau and sport tourism, touristic infrastructure and possibilities and the regions declared to be tourism centre.

\section{Plateau Tourism}

Plateau festivals are held in Doğankent in summer months, which have great contributions to the development of tourism in the area and are evaluated to be the time period and events when people away from their homeland can have opportunity to meet their relatives. A number of people participate in the summer festivals (Table 1).Harmancik Plateau Festival is among such festivals held in summer months with high participation (Figure 1).

Tab. 1. Social activities performed in summer months in the area

\begin{tabular}{|l|l|l|}
\hline Name of the festival & Month & Area \\
\hline Summer festivals & August & Doğankent \\
\hline Güvenlik Village Spring Festival & June & Doğankent-Güvende Village \\
\hline Harmancık Plateau Festival & August & Doğanken Harmancık Plateau \\
\hline
\end{tabular}



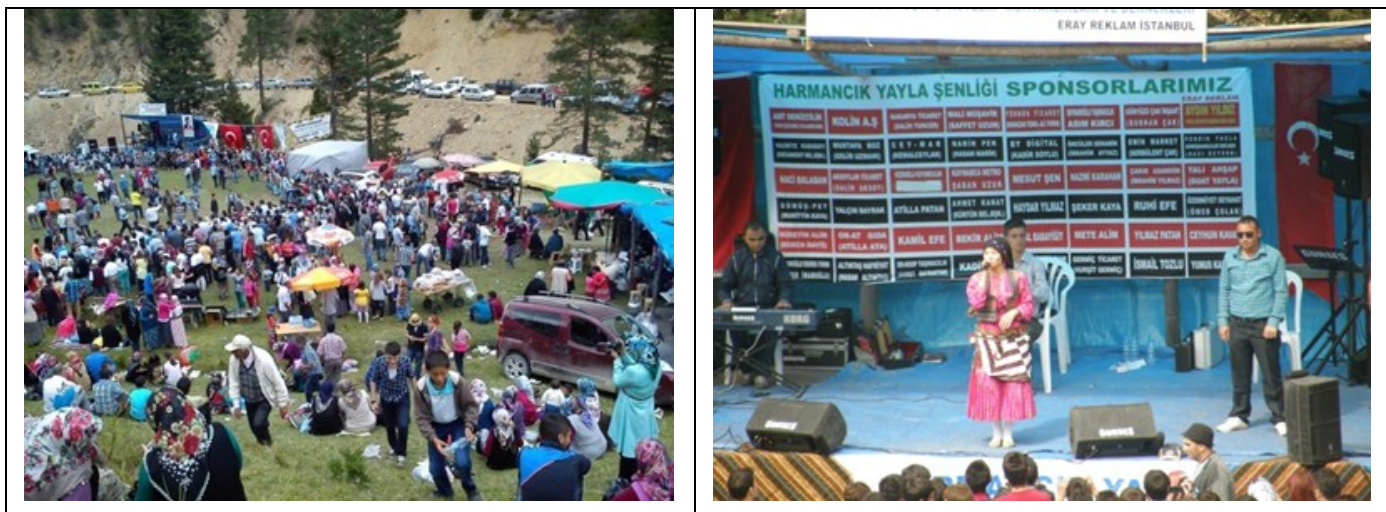

Fig. 1. Harmancik festival

Traditional life style examples from Doğankent plateaus are given in Figure 2.
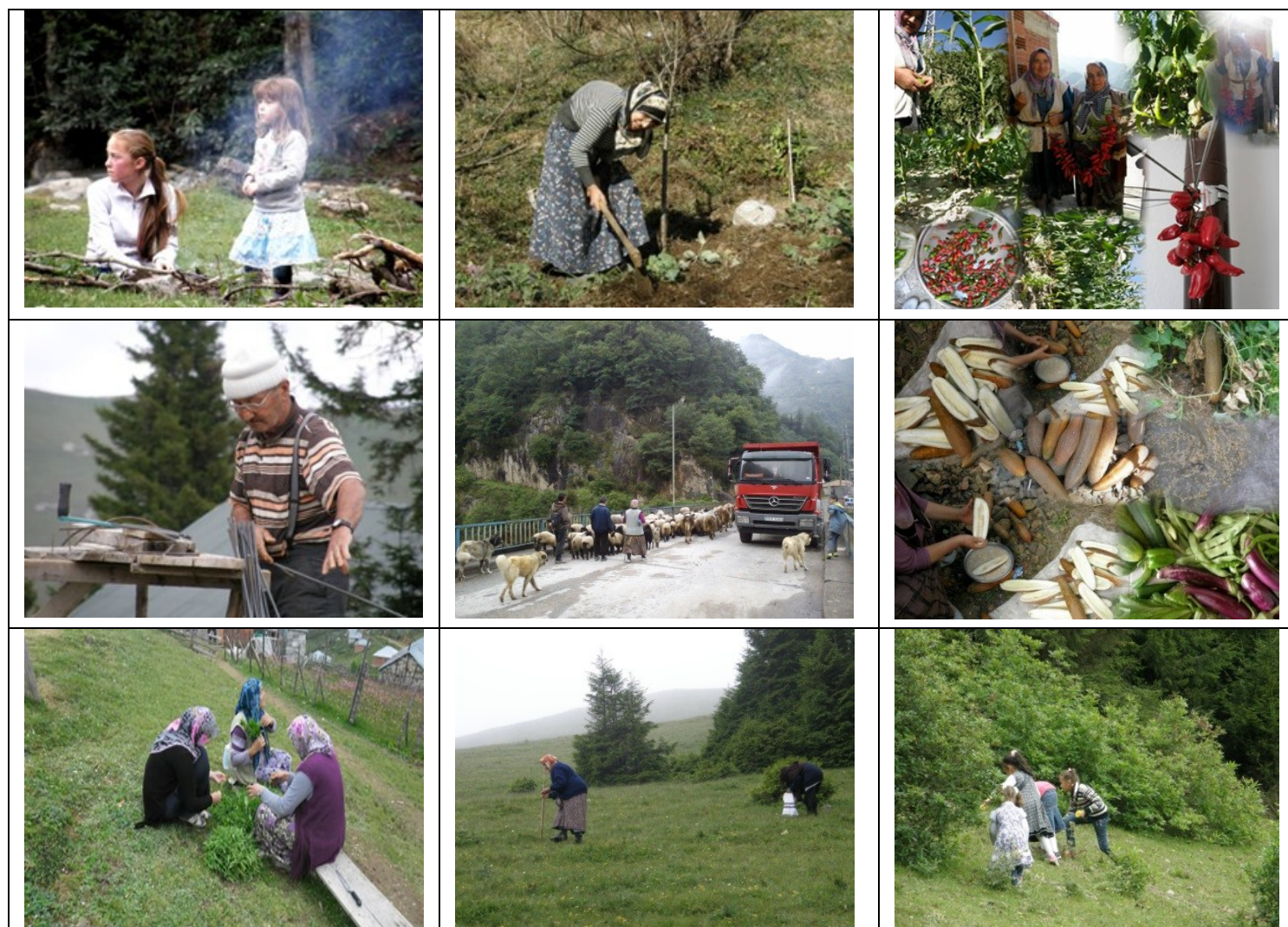

Fig. 2. Traditional life in Doğankent plateaus

Kayabaşı is the closestplateau to Doğankent and at an elevation of $2000 \mathrm{~m}$. It has the largest plain area among East Blacksea Plateaus and unique beauty. It also attracts attentions with its floristic characteristics (Figure 3) and offers suitable areas for excursions, picnic activities, grass skiing, mountaineering and climbing and shelters steep cliffs, strong and carpet - like turf surface surrounded by rhododendrons, spruce, fir and hornbeam trees. 


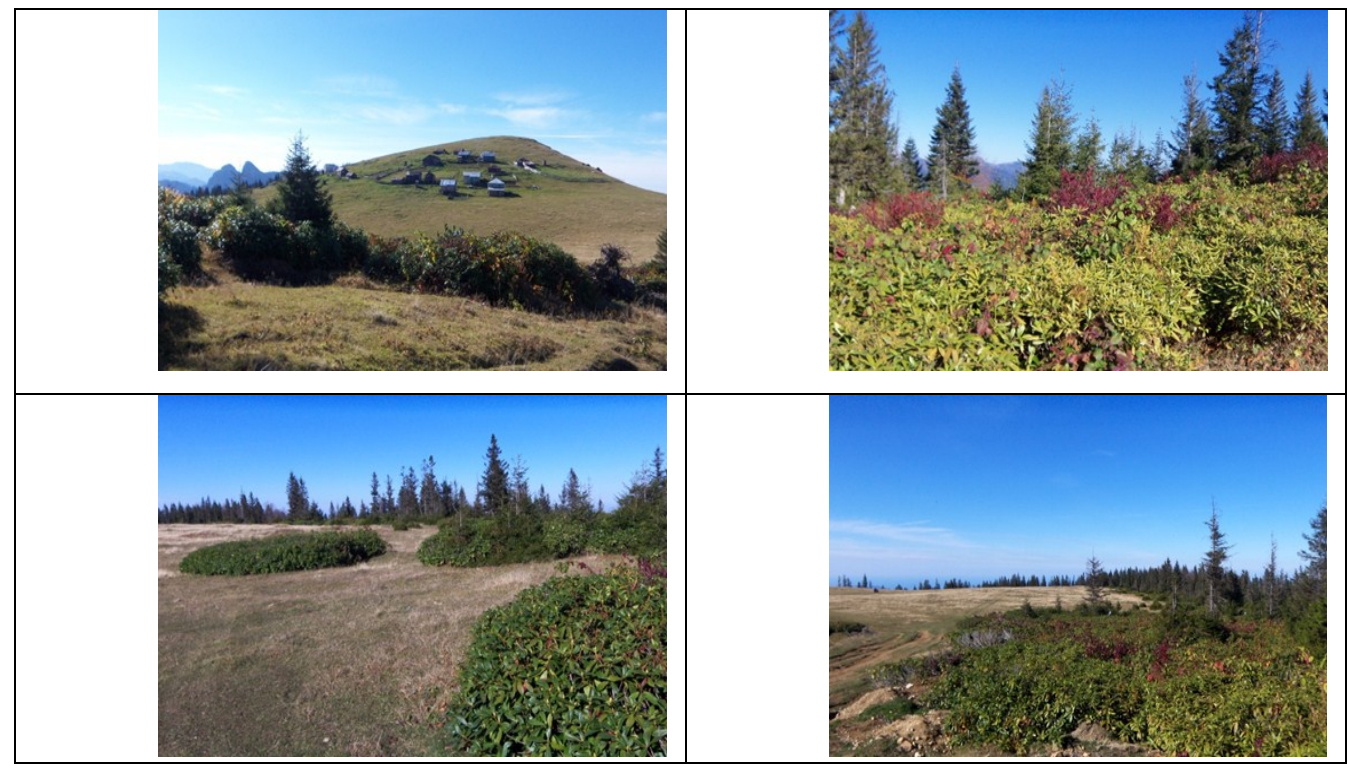

Fig. 3. Overviews from Kayabaşı plateau

Yaşmakl1-Ağaçbaşı plateau, $25 \mathrm{~km}$ south of Doğankent district centre, is at an elevation of $1900 \mathrm{~m}$ and used by locals staying there in nearly 200 houses from May to October and occupying small scale livestock breeding. The area is covered with hornbeam tree, redwoods and pine trees (Anonymous 2011).

Dandi Tepealan plateau, $17 \mathrm{~km}$ south of Doğankent district centre, breaking point in the old days for locals going up plateaus and now used as picnicand recreation area by people living in Süttaş1 neighbourhood (Anonymous 2011).

Bonyurt plateau is hidden in a forest and used by people living in Güvenlik village and Yeni Mahalle neighbourhood. It has borders with several other plateaus and is used by people not only staying in plateau but also living in other areas.

The plateau gets sun early in the morning but in the afternoon it is densely foggy and a summer day may turn into an autumn day. When fog disperses it leaves its place a fascinating beauty(Figure 4).

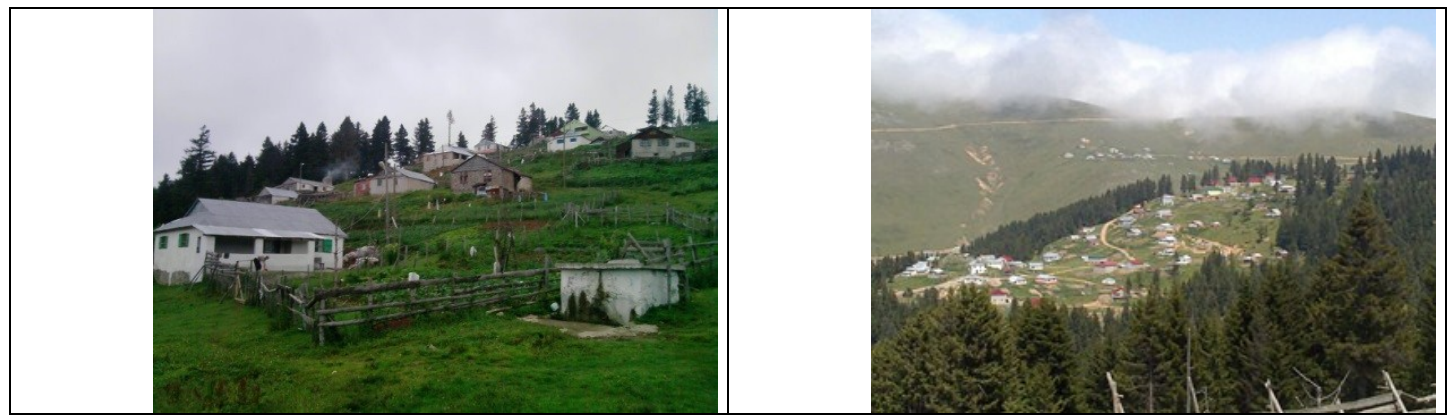

Fig. 4. Overview from Bonyurt plateau 


\section{History and culture tourism}

The study area full of various types of historical remains and cultural elements belonging to various civilisations attracts attentions for history and culture. The area contributed to Turkish cultural life both in Seljukians and Ottoman and Republic periods.

Fortresses (e.g. those called Dandi, Şadı and Tingır) located in the border of Doğankent are accepted to be potential source values for history and culture tourism.

In the $1^{\text {st }}$ World War years, the area witnessed the defence of Turkish army and great number of soldiers were killed in the war. In recent years, during the construction of a road, bodies of these soldiers were found and some martyrdoms have been constructed. These martyrdoms (e.g. Akdoğan, Kabaktepe, Abadan Plateau, Turna Hill, Güvende, Masur Plateau, Harşit and Aslancık) are visited by tens of people each year and counted among the important sites for history tourism.

Historical Russian Road with a length of $6 \mathrm{~km}$ and paved with stones is $22 \mathrm{~km}$ away from Doğankent city centre, at an elevation of $1383 \mathrm{~m}$ and a view of north west. It was once used to reach mines and carry the materials to the coast.

Due to geographical conditions, settlement type is dispersed housing. People growing plant and animal have transformed the suitable areas into field to produce plant and basement level of their houses were also used for animal shelter. Animal breeding is only performed limited to meet the need of a family. Since urban people did not disconnect with their relatives in rural / villages, most of the traditions are alive today in cities. Figure 5 represents the samples from traditional life.

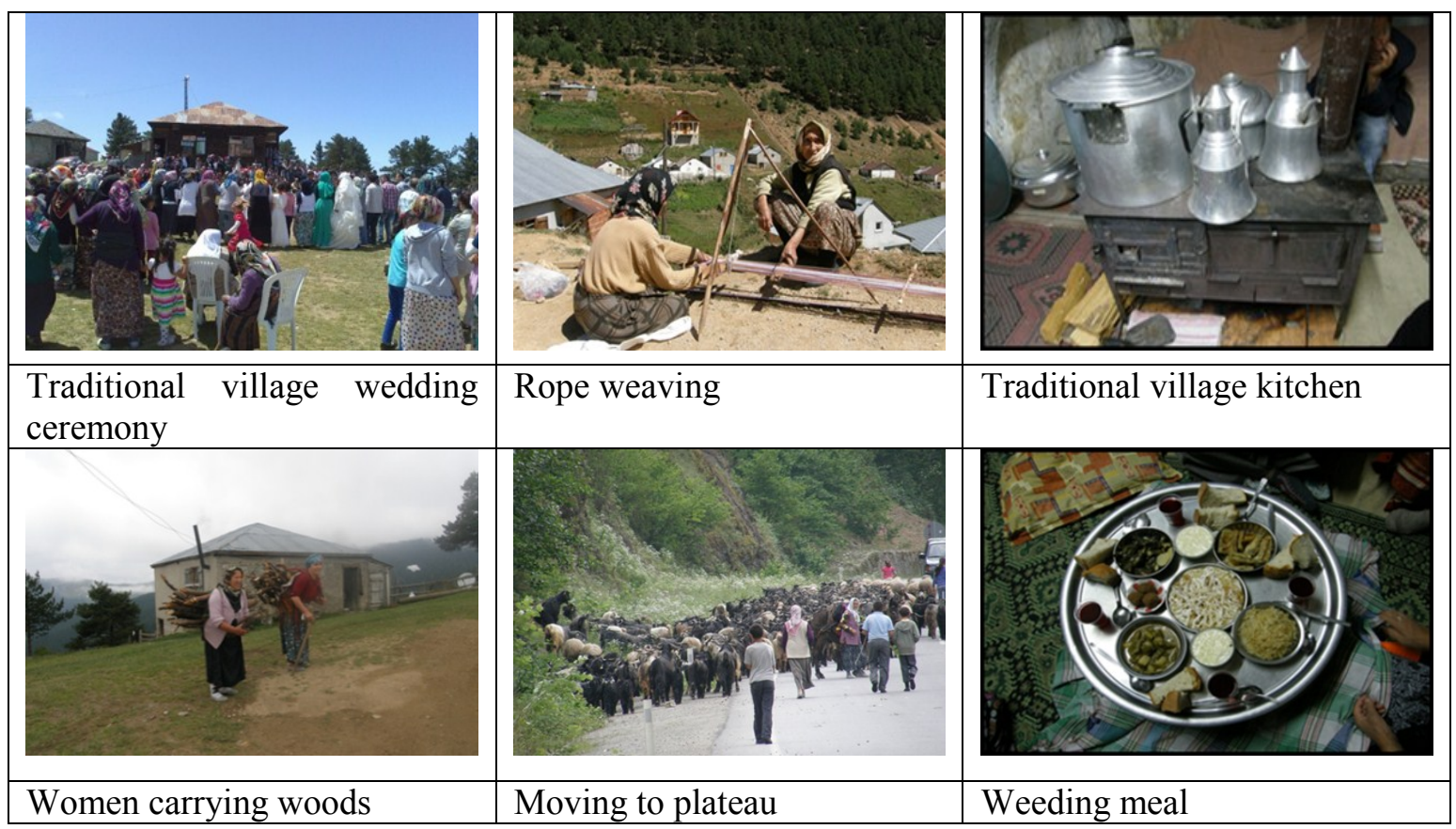

Fig. 5. View from traditional life

Traditional clothes for men are typical of Blacksea region involving a kind coat, shirt, pants, black cap, and specially designed boats and some accessories such as belt, knife or 
gun while for women, under-shirt, shirt, three folded skirt, breast cloth, cloak, a type of pants, belt, cap, head cover, wool socks and leather shoes.

\section{Gastronomy Tourism}

Nut is grown in Doğankent and used in various types of food. Pastries (salty and seweet) take place in the cusine culture of the area. The most famous dish called "Siron" is made of phyllo dough (thin dough plates). Deserts made of dough (burma and baklava) are also traditionally most consumed. Fried pickled grape and other pickle types, boiled and filled black mustard and corn bread are unique to the area (Figure 6).

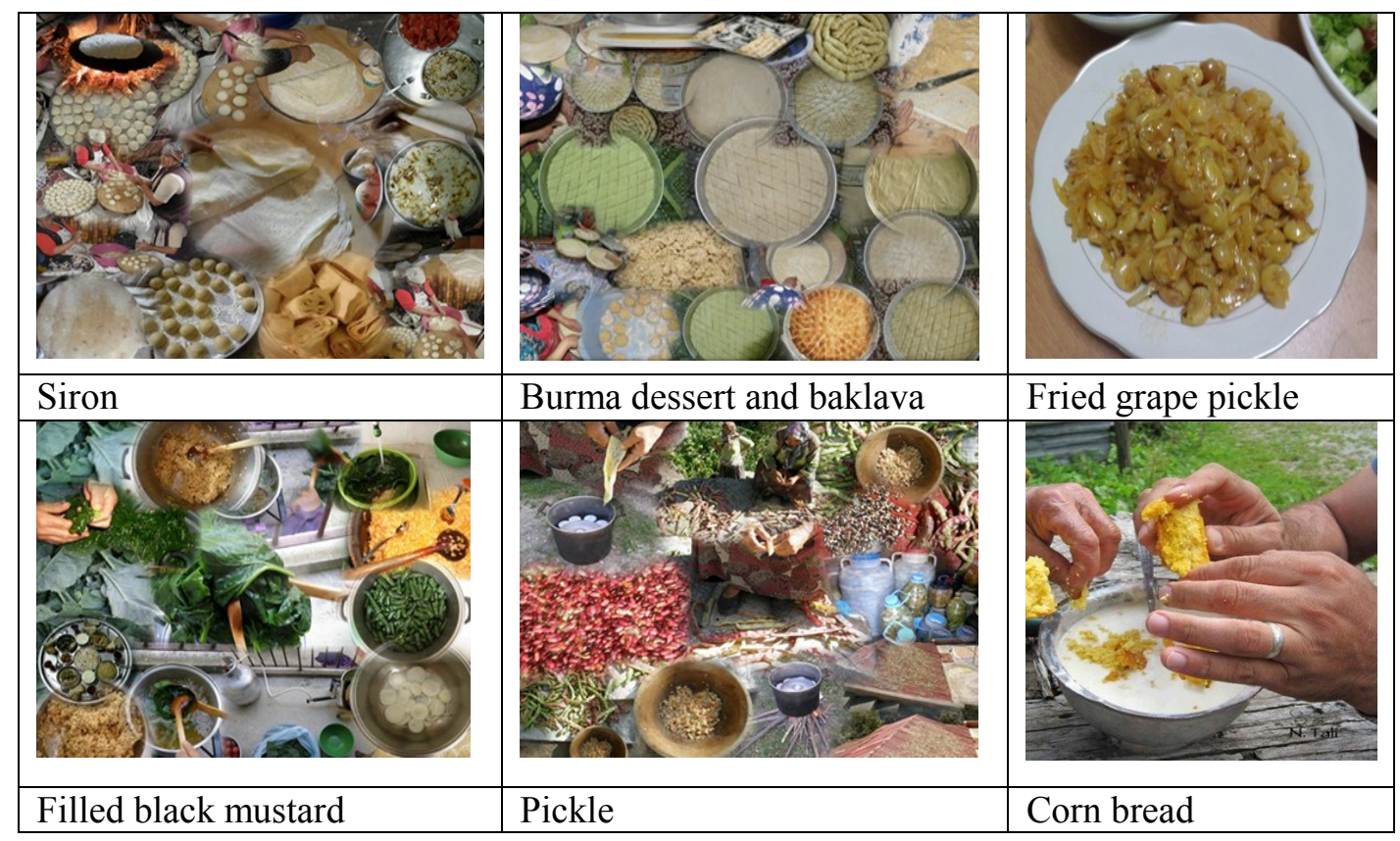

Fig. 6. Traditional dishes of Doğankent

Cherry and cheese are saved for winter use while some fish can be saved for summer by salting. Beet soup, filled corn, fired cherry pickle, bean pickle and corn bread are among the famous and unique dishes.

\section{Winter tourism}

Snow depth increase due to the elevation and climate of the area. Some climatic parameters like snowy period and depth of snow cover show the suitability of the area for winter tourism. However, the area has no winter tourism facilities.

\section{Water based tourism}

Several waterfalls and creeks are present in the area. Water based activities like fish hunting can be performed in creeks. Çatalağaç Waterfall, Erik creek and Doymuş waterfall are among the important water sources. Karagöl at the end of Doymuş waterfall on Harşit creek is suitable for swimming and its surrounding is used for recreation activities. 


\section{Flora Tourism}

The area is very rich in plant diversity by representing the plant cover prevalent in East Blacksea Region. Between the elevations of 800 to $1200 \mathrm{~m}$, tree species take place like oriental spruce (Picea orientalis), Scotch pine (Pinus silvestris), fir (Abies nordmannian), ash (Fraxinus orientalis), oak (Quercus robur). Above $2000 \mathrm{~m}$, alpine belt species can be seen like Laurocerasus officinalis, Rhododendron sp, daphnia(Laurus nobilis), boxwood (Buxus sempervirens).

Grassy plants mostly seen in plateaus are Ajuga orientalis, Colchichum sp., Anthemis sp., Daphne glomerata Lam., Primula elatior L., Rhondodendron ponticum L. and Taraxacum sp. (Figure 7).

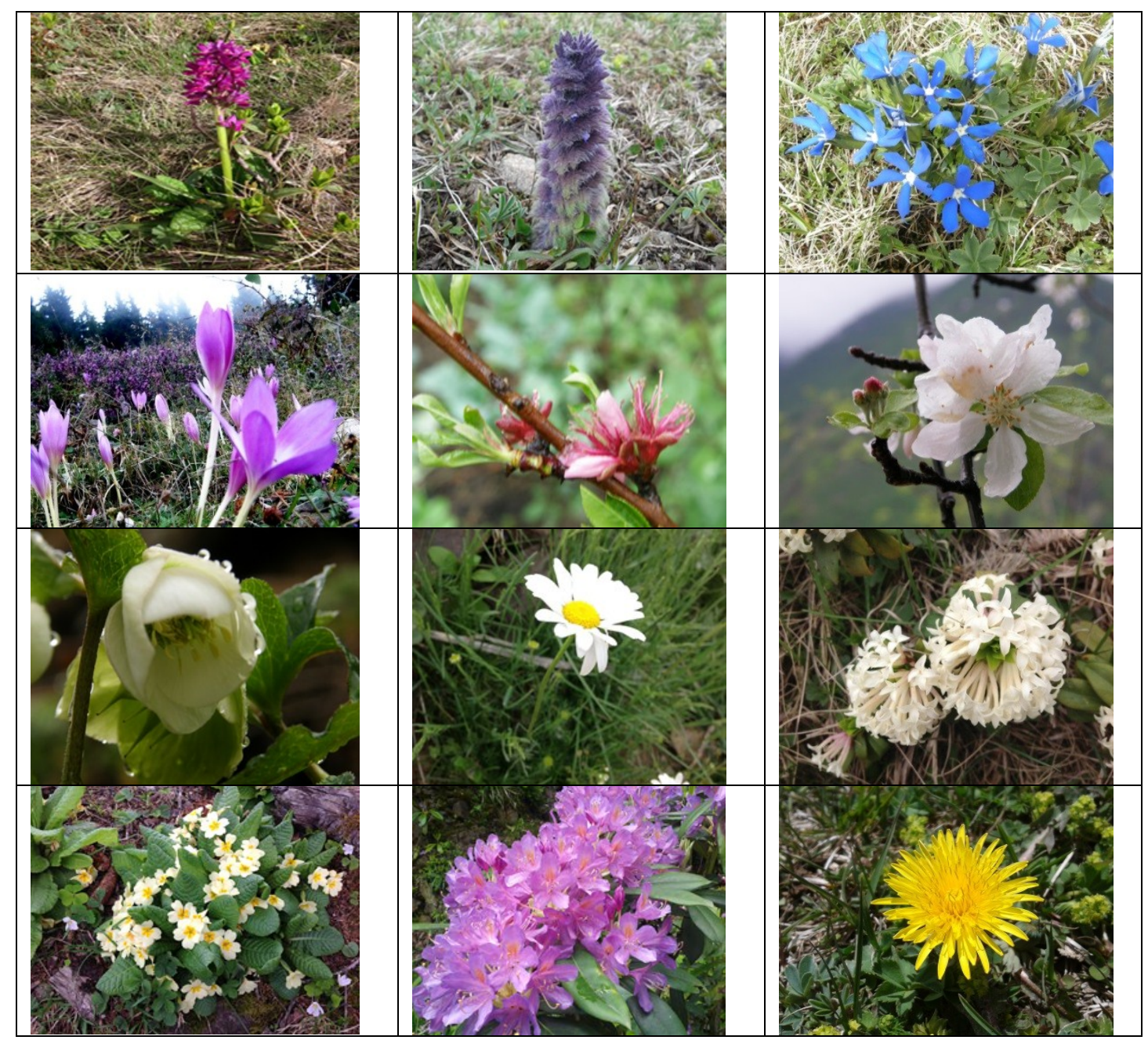

Fig. 7. Some plant species in the area 


\section{Source values for the sport tourism}

Hunting is an indispensable hobby for wild animal diversity, vast hunting areas, long winters and people's interest. Study area, $89 \%$ of which is made of mountains and plains offers periodic or permanent hunting possibility.

7.1. Trekking:the area is suitable for people who desire to run away from crowded and noisy urban life and spend a day in nature and share beauties in nature.

7.2. Orienteering: It requires finding direction using a map in a certain tie period. Although it is possible to make this sport under different surface conditions forests are preferred more. Study area is rich in forest area.

7.3. Mountain marathon:This sport type requires walking or running for long in steep land, resistance and finding direction. Study area offers suitable areas for this sport with its topographic features.

7.4. Flatwater motorboat races and other water sports: Such races can be performed on flatwater or slowly running water surfaces, which can be offered by lakes deeper than 80 $\mathrm{cm}$ and facing windless weather. Windless, calm, protected bays or slowly moving rivers can be used for this sport. In the area Harşit creek and Kavraz stream meet these criteria.

7.5. Mountaineering:The area offers suitable routes for mountaineering with the roughness beginning from 190 mclimbing up to3320 m.

7.6. Jeep-Safari; the area owns important value sources for jeep-safari with bent, narrow, exciting and steep roads passing through the plateaus.

\section{RESULTS}

Existent and proposed tourism potentials were determined in the study as the results of the observations and data evaluated. Doğankent attracts attention with its plateaus. Therefore, plateau tourism is in the first row among the tourism activities in the area. Due to the festivals frequently held in plateaus festival tourismis also forefront.

Historical and cultural diversity and traditional dietary habits present possibilities for history and culture and gastronomy tourism. Cold winter conditions are prevalent in plateaus and temperatures are very low and the number of snowy days is large. These conditions are accepted to be potentials for winter tourism. The area also shelters high biodiversity rate and therefore has potentials for flora tourism, plant, bird and butterfly watching and photo -safari.

For the water based activities the area offers potentials with its natural structure for the sportive activities e.g. hunting fish with line, nature sports, hunting, trekking, orienteering, paragliding, mountain marathon, motorboat races and other water sports, mountaineering, jeep-safari, horse riding in nature and mountain biking.In addition, the area is suitable for camping and caravan tourism and agro- tourism.

\section{REFERENCES}

1. Anonymous (2011): Giresun Çevre Durum Raporu, Ankara.

2. Çeken, H., Karadağ, L., Dalgın, T. (2007). Kırsal Kalkınmada Yeni Bir Yaklaşım Kırsal Turizm Ve Türkiye'ye Yönelik Teorik Bir Çalışma. Artvin Çoruh Üniversitesi Orman Fakültesi Dergisi, 8 (1), 1-14. 
3. Çil Yavuz, N., (2006): Test For The Effect Of Tourism Receipts On Economic Growth In Turkey: Structural Break And Causality Analysis, Dogus University Journal, 7 (2): 162-171.

4. Emekli, G., (2005): The Policies of the Tourism in European Union and Cultural Tourism in Turkiye. Aegean Geographical Journal, 14: 99-107.

5. Emekli, G., (2006): Geography, Culture and Tourism: Cultural Tourism. Aegean Geographical Journal, 15: 51-59.

6. Kasalak, M.A., (2015): Ecotourism Market In The World And Contributions To The State Income Of Ecotourism, Journal of Recreation and Tourism Research, 2(2):20-26.

7. Gökalp, D.D., Yazgan, M.E., (2013): Rural Landscape Planning in AgroTourism and Agri-Tourism. Karamanoğlu Mehmetbey UniversityJournalofSocialand Economic Research, 15 (24): 25-29.

8. Tolungüç, A., (1999): Turizm Olgusu ve Türk Turizmi. Ankara: Mediacat Yayınlar1 